\title{
Cellular Nucleic Acid-Binding Protein
}

National Cancer Institute

\section{Source}

National Cancer Institute. Cellular Nucleic Acid-Binding Protein. NCI Thesaurus. Code C97890.

Cellular nucleic acid-binding protein (177 aa, $19 \mathrm{kDa}$ ) is encoded by the human CNBP gene. This protein is involved in the modulation of the expression of sterol responsive genes. 